\title{
Caspase activity and expression of cell death genes during development of human preimplantation embryos
}

\author{
S. Spanos ${ }^{1}$, S. Rice ${ }^{1}$, P. Karagiannis ${ }^{1}$, D. Taylor ${ }^{1}$, D. L. Becker ${ }^{2}$, \\ R. M. L. Winston ${ }^{1}$ and K. Hardy ${ }^{1 *}$ \\ ${ }^{1}$ Department of Reproductive Science and Medicine, Institute of Reproductive and \\ Developmental Biology, The Wolfson and Weston Research Centre for Family Health, \\ Imperial College, Hammersmith Hospital, Du Cane Road, London W12 ONN, UK; and \\ ${ }^{2}$ Department of Anatomy and Developmental Biology, University College London, \\ Gower Street, London WC1 6BT, UK
}

It has been observed that apoptosis occurs in human blastocysts. In other types of cell, the characteristic morphological changes seen in apoptotic cells are executed by caspases, which are regulated by the BCL-2 family of proteins. This study investigated whether these components of the apoptotic cascade are present throughout human preimplantation development. Developing and arrested two pronucleate embryos at all stages were incubated with a fluorescently tagged caspase inhibitor that binds only to active caspases, fixed, counterstained with 4,6-diamidino-2-phenylindole (DAPI) to assess nuclear morphology and examined using confocal microscopy. Active caspases were detected only after compaction, at the morula and blastocyst stages, and were frequently associated with apoptotic nuclei. Occasional labelling was seen in arrested embryos. Expression of proapoptotic BAX and BAD and anti-apoptotic BCL-2 was examined in single embryos using RT-PCR and immunohistochemistry. BAX and BCL-2 mRNAs were expressed throughout development, whereas BAD mRNA was expressed mainly after compaction. Simultaneous expression of BAX and BCL-2 proteins within individual embryos was confirmed using immunohistochemistry. The onset of caspase activity and BAD expression after compaction correlates with the previously reported appearance of apoptotic nuclei. As in other types of cell, human embryos express common molecular components of the apoptotic cascade, although apoptosis appears to be suppressed before compaction and differentiation.

\section{Introduction}

There is increasing evidence that cells in mammalian preimplantation embryos undergo apoptosis (for a review, see Hardy, 1997; Betts and King, 2001). Characteristic apoptotic features, including fragmenting nuclei and nuclei with fragmented DNA, are rarely seen before compaction, but are commonly seen in blastocysts from a number of mammalian species, including humans (Hardy, 1999; Hardy et al., 2001), mice (Handyside and Hunter, 1986; Brison and Schultz, 1997) and cows (Byrne et al., 1999; Matwee et al., 2000). Levels of apoptosis can be environmentally regulated (Brison and Schultz, 1997; Pampfer et al., 1997; Moley et al., 1998; Spanos et al., 2000) but the role remains unknown (Hardy, 1997).

Two major protein families are central to the regulation and execution of apoptosis, the BCL-2 and caspase families, which are highly conserved from worms to humans (Aravind et al., 1999). The caspase family of cysteine proteases mediates proteolytic cleavage of a large number

${ }^{*}$ Correspondence

Email: k.hardy@ic.ac.uk of proteins leading to the apoptotic morphology observed in cells, including the formation of fragmented nuclei and apoptotic bodies (Earnshaw et al., 1999). Each caspase is synthesized as an inactive precursor, which is activated only after a cell has received a death signal. Activated upstream caspases, known as initiator caspases, activate downstream executor caspases (which cleave proteins important for cell survival and integrity) and endonucleases (which cleave DNA) (Nagata, 2000).

The BCL-2 family, which is involved in the regulation of caspase activity, is subdivided into pro-apoptotic (for example BAX and BAD) and anti-apoptotic members (for example BCL-2), which share one or more similar regions (Tsujimoto and Shimizu, 2000; Adams and Cory, 2001). Many members of the BCL-2 family can form homo- and heterodimers (Wang and Reed, 1998; Tsujimoto and Shimizu, 2000) and it is thought to be the ratio between proand anti-apoptotic proteins that determines whether a cell lives or dies (Oltvai et al., 1993; Wyllie, 1995), although some proteins may act independently. The mechanism of action of the BCL-2 family (Adams and Cory, 2001) almost certainly involves changes in mitochondrial permeability, either by mitochondrial swelling and physical disruption or 
by pore formation (Vieira and Kroemer, 1999; Tsujimoto and Shimizu, 2000; Bernardi et al., 2001). Apoptotic mitochondrial changes are mainly prevented by anti-apoptotic proteins, such as BCL-2, located in the outer mitochondrial membrane, as well as the nuclear envelope and endoplasmic reticulum. However, during apoptosis, pro-apoptotic members (for example BAX and BAD) are activated, translocating from the cytosol to the mitochondria (Hsu et al., 1997; Wolter et al., 1997). In this way, the BCL-2 family of proteins is believed to regulate the release and activation of pro-apoptotic factors from mitochondria, such as cytochrome $c$ and apoptosis-inducing factor, that lead to the activation of caspases and other downstream execution proteins and ultimately cell death.

Until recently, little was known about the expression of the BCL-2 and caspase families in preimplantation embryos. In the mouse, mRNAs for anti-apoptotic Bcl-2, Bcl- $\mathrm{x}_{\mathrm{L}}$ and $\mathrm{BCl}-\mathrm{w}$ and pro-apoptotic Bax, Bak, Bad and $\mathrm{BCl}_{-} \mathrm{x}_{\mathrm{s}}$ were found throughout preimplantation development (Jurisicova et al., 1998; Warner et al., 1998b; Exley et al., 1999), and Bax and $\mathrm{Bcl}-2$ protein is found in mouse and rat blastocysts, respectively (Moley et al., 1998; Pampfer et al., 2001). Both $\mathrm{Bax}$ and $\mathrm{BCl}-2$ play a role in the regulation of apoptosis in the rodent preimplantation embryo; mouse blastocysts deficient in Bax and rat blastocysts with antisense-blocked $\mathrm{BCl}-2$ expression are resistant to high-glucose-induced apoptosis (Moley et al., 1998; Pampfer et al., 2001). Expression of mRNA for caspases 2, 3, 6, 7 and 12 was also found throughout mouse preimplantation development (Exley et al., 1999).

Little is known about the expression of these regulatory proteins in human embryos. Both mRNA and protein for BAX and BCL-2 have been found in early uncompacted embryos (Warner et al., 1998a; Antczak and Van Blerkom, 1999; Liu et al., 2000), but there is no information about expression at the morula and blastocyst stages.

The present study examined for the first time the expression of mRNA for BCL-2, BAX and BAD and immunohistochemically localized BCL-2 and BAX in human embryos throughout development from the two- to four-cell stage to the blastocyst stage. BCL-2 and BAX were examined as they are representative and widely expressed examples of anti- and pro-apoptotic members of the BCL-2 family that are involved in the regulation of apoptosis in rodent embryos, and the ratio of which is thought to determine the fate of the cell. Expression of BAD was investigated because of its central role as a key mediator in the apoptotic pathway triggered by growth factor deprivation, such as the insulin-like growth factor I (IGF-I)-regulated pathway (Spanos et al., 2000). Finally, the hypothesis that caspases are involved in generating the classic apoptotic morphology commonly seen after compaction in human embryos (Hardy et al., 2001) was investigated.

\section{Materials and Methods}

\section{Human oocytes and embryos}

Oocytes and embryos were donated with informed consent by infertile couples undergoing IVF, who did not wish to cryopreserve untransferred embryos for future replacement. The work was conducted under licence from the Human Fertilisation and Embryology Authority (HFEA) and local ethical permission was granted by the ethics committee of Imperial College School of Medicine, Hammersmith Hospital, London.

Superovulation and IVF were carried out as described by Spanos et al. (2000). Approximately 16-18 h after insemination (day 0 = day of insemination), oocytes were classified according to the number of visible pronuclei. Embryos were initially cultured individually in $1 \mathrm{ml}$ of Earle's balanced salt solution (EBSS; Gibco BRL, Paisley) containing $5.56 \mathrm{mmol}$ glucose $\mathrm{I}^{-1}, 25.0 \mathrm{mmol}$ sodium bicarbonate $\mathrm{I}^{-1}$ (BDH, Lutterworth), $0.47 \mathrm{mmol}$ pyruvate $\mathrm{I}^{-1}$ (Sigma, Poole), $37.5 \mathrm{U}$ streptomycin $\mathrm{ml}^{-1}$ (Sigma) and $97.5 \mathrm{U}$ penicillin $\mathrm{ml}^{-1}$ (Sigma) and supplemented with $10 \%$ heatinactivated maternal serum, under a gas phase of $5 \% \mathrm{CO}_{2}$, $5 \% \mathrm{O}_{2}$ and $90 \% \mathrm{~N}_{2}$ at $37^{\circ} \mathrm{C}$.

On the morning of day 2, embryos were graded on the basis of blastomere symmetry and degree of fragmentation (Dawson et al., 1995). Oocytes that were unfertilized on day 2 and two pronucleate arrested and developing embryos of various morphologies were selected for study. From day 2, embryos were cultured individually in $5 \mu \mathrm{l}$ droplets of custom-made glucose-free EBSS supplemented with $1 \mathrm{mmol}$ L-glutamine I $^{-1}$ (Sigma) (Devreker et al., 1998) and 4 mg IGF-free BSA ml-1 (Sigma) (Spanos et al., 2000), overlaid with silicone fluid (Dow Corning 200/50cS; BDH). Culture media were prepared weekly from stock solutions and stored at $4{ }^{\circ} \mathrm{C}$ before use. Embryos were transferred to fresh $5 \mu \mathrm{l}$ droplets of culture medium at $24 \mathrm{~h}$ intervals. All oocytes and embryos were monitored and treated individually throughout the entire experimental procedure.

Some cryopreserved embryos were used as part of the active caspase labelling study. Twenty embryos that had been cryopreserved between day 1 and day 3 , and that had contained two pronuclei on day 1, were thawed. The embryos were donated for research with informed consent. Frozen embryos in straws were removed from liquid nitrogen and placed in a $37^{\circ} \mathrm{C}$ waterbath for $30 \mathrm{~s}$. Embryos were then flushed into $1.0 \mathrm{~mol}$ 1,2, propanediol $\mathrm{I}^{-1}$ (Sigma) in PBS (Gibco BRL) supplemented with $8 \mathrm{mg} \mathrm{BSA} \mathrm{ml}^{-1}$ (Sigma) (PBS-BSA) at room temperature and incubated for $5 \mathrm{~min}$, before being taken through a series of thawing solutions: 0.5 mol 1,2,propanediol $\mathrm{I}^{-1}$ in PBS-BSA (5 min); $0.2 \mathrm{~mol}$ sucrose $\mathrm{I}^{-1}$ in PBS-BSA (Analar, BDH) (10 min); PBS-BSA alone $(10 \mathrm{~min})$. After the final incubation in PBS-BSA, embryos were examined for thawing damage. Surviving embryos with intact blastomeres were cultured as described above in $5 \mu \mathrm{l}$ droplets of glucose-free EBSS under silicone fluid for $\geqslant 24 \mathrm{~h}$. Surviving embryos of good morphology that cleaved during culture after thawing were cultured to various stages before labelling for active caspases.

\section{Reverse transcription $(R T)$}

All chemicals were from Sigma unless otherwise stated. After zona pellucida removal with acid Tyrode's $(\mathrm{pH}$ 
2.3-2.4) (ZD ${ }^{\mathrm{TM}}-10$ Scandinavian IVF Science AB; Hunter Scientific Ltd, Saffron Waldon), individual oocytes and embryos were washed in sterile PBS and lysed in $5 \mu$ lysis buffer (0.5\% IGEPAL CA-630, $10 \mathrm{mmol}^{\text {Tris }} \mathrm{l}^{-1}(\mathrm{pH} 8.0)$, $10 \mathrm{mmol} \mathrm{NaCl} \mathrm{I}^{-1}$ and $3 \mathrm{mmol} \mathrm{MgCl}_{2} \mathrm{I}^{-1}$ ) on ice (Gilliland et al., 1990). If reverse transcription was not carried out immediately, lysates were snap frozen in liquid nitrogen and stored at $-70^{\circ} \mathrm{C}$ for a maximum of 2 weeks. The lysate was made up to $20 \mu \mathrm{l}$ with $1 \mu \mathrm{l}$ of a $10 \mathrm{mmol}$ dNTP mix $\mathrm{I}^{-1}$ (100 $\mu$ leach of 100 mmol dATP $~^{-1}$, dUTP, dCTP and dGTP (Pharmacia, New Jersey) in $600 \mu \mathrm{l}$ RNase-free water), $2 \mu \mathrm{l}$ of 0.1 mol dithiothreitol I-1 (DTT; Gibco BRL), $1 \mu$ of $5 \times$ first strand buffer (Gibco BRL), with and without (negative control) $1 \mu \mathrm{l}\left(200 \cup \mu \mathrm{I}^{-1}\right)$ Moloney Murine Leukemia Virus (M-MLV) reverse transcriptase (Gibco BRL) and $1 \mu \mathrm{l}(0.5 \mu \mathrm{g})$ oligo(dT) ${ }_{12-18}$ primer (Gibco BRL) before incubation at $37^{\circ} \mathrm{C}$ for $1 \mathrm{~h}$. The reaction was terminated by heating the tubes at $99^{\circ} \mathrm{C}$ for 5 min before immediately placing on ice. All tubes were centrifuged at $10000 \mathrm{~g}$ for $1 \mathrm{~min}$ and the supernatant was used for nested PCR, or stored at $-20^{\circ} \mathrm{C}$ until further use.

\section{Nested RT-PCR and gel electrophoresis}

Oligonucleotide primer pairs derived from human sequences of BCL-2, BAX and BAD were designed using Primer3 Output (http://www.genome.wi.mit.edu/genome_ software/other/primer3.html) and synthesized chemically (Oswel, Bassett Crescent East, Southampton). Primer pairs derived from the cloned sequence for human $\beta$-actin (Ponte et al., 1984) were included as a positive control to evaluate the quality of the cDNA prepared from the oocytes and embryos, the PCR procedure and to test for genomic contamination. All primers spanned introns so that product derived from contamination with genomic DNA would be larger than the cDNA product of RT-PCR. Oligonucleotide primer pairs, annealing temperatures and expected sizes of amplified PCR products are summarized (Table 1). Granulosa or placental cDNA was used as a positive control.

After reverse transcription, $5 \mu \mathrm{l}$ of reverse transcribed cDNA product was made up to $50 \mu \mathrm{l}$ with $5 \mu \mathrm{l}$ of $10 \times$ PCR buffer II (Applied Biosystems, Roche, Welwyn Garden City), $0.5 \mu \mathrm{l}$ of $10 \mathrm{mmol}$ dNTP mix l-1, $3 \mu \mathrm{l}$ of $25 \mathrm{mmol} \mathrm{MgCl}_{2}$ solution $\mathrm{I}^{-1}$ (Applied Biosystems), $0.5 \mu \mathrm{l}\left(5 \cup \mathrm{I}^{-1}\right)$ Taq polymerase (AmpliTaq; Perkin Elmer, Roche, Beaconsfield) and $1 \mu \mathrm{l}$ of each $40 \mathrm{ng}$ primer $\mathrm{ml}^{-1}$. PCR conditions were denaturation at $94^{\circ} \mathrm{C}$ for $1 \mathrm{~min}$, annealing at the temperature specified for each primer set (Table 1) for $1 \mathrm{~min}$, extension at $72^{\circ} \mathrm{C}$ for $90 \mathrm{~s}$ and a final extension of $6 \mathrm{~min}$. PCR was carried out using a PCR express thermal cycler (Hybaid Ltd, Ashford). The outer primers were run for 25 cycles, and nested primers for 30-35 cycles. For the nested reaction, $5 \mu \mathrm{l}$ of the first amplification product was added to freshly prepared PCR mix. Ten microlitres of each amplification product was separated on $2 \%(\mathrm{w} / \mathrm{v})$ agarose gel (Gibco, BRL), stained with ethidium bromide (Sigma) and photographed under UV light. PCR products were verified using restriction digest analysis (Table 1 ) and sequencing.

\section{Immunohistochemistry}

Two pronucleate embryos at different stages were processed individually for immunohistochemistry. All PBS was filtered with a $0.22 \mu \mathrm{m}$ filter (Millipore, Watford). Single embryos were washed twice in approximately $100 \mu \mathrm{l}$ filtered PBS supplemented with $3 \mathrm{mg}$ polyvinylpyrrolidone $\mathrm{ml}^{-1}$ (PVP; Sigma) (PBS-PVP, pH 7.4). Embryos were fixed with $4 \%(\mathrm{w} / \mathrm{v})$ paraformaldehyde (Sigma) $(1 \mathrm{~h}$ at room temperature) before washing twice with PBS-PVP and staining with $1 \%(\mathrm{v} / \mathrm{v})$ eosin (Merck, West Drayton) aqueous solution (30 s) to facilitate visualization of the embryo during sectioning. Embryos were then placed individually in $2 \%(\mathrm{w} / \mathrm{v})$ liquid agarose gel (low gelling temperature $<30^{\circ} \mathrm{C}$ ) (Sigma) and left overnight at room temperature to set. A small section of the gel containing the embryo (approximately $3 \mathrm{~mm} \times 3 \mathrm{~mm}$ ) was excized with a scalpel, dehydrated through a series of alcohol (Analar, BDH: $70 \%$, $1.0 \mathrm{~h} ; 90 \%, 1.0 \mathrm{~h} ; 100 \%, 1.5 \mathrm{~h})$ and placed in xylene (Histoclear; National Diagnostics, Hessle) for 1 h. Specimens were embedded in paraffin wax (Surgipath Europe Ltd, Peterborough), cut into serial sections $(5 \mu \mathrm{m})$ and retrieved on poly-L-lysine-coated microscope slides (BDH). Paraffin wax was removed from the sections in three changes of xylene (10 min each) and the sections were then hydrated through a series of alcohol (Analar, $\mathrm{BDH}$ : $10 \mathrm{~min}$ each $100 \%$, twice; $90 \%$, twice; $70 \%$, twice; and finally $5 \mathrm{~min}$ in distilled water, twice).

Individual dewaxed sections from each embryo were distributed equally between control (no primary antibody), and staining for BAX and BCL-2, using rabbit polyclonal antibodies (Oncogene Research Products, CN Biosciences (UK) Ltd, Beeston, Nottingham). Antibodies were used at a dilution of $2 \mu \mathrm{g} \mathrm{ml}^{-1}$ (1:50 dilution, as determined by dilution curve) in 1\% PBS-BSA. All incubations were carried out in a humidified chamber at ambient temperature (unless otherwise stated). Sections were incubated for $10 \mathrm{~min}$ in $0.1 \%(\mathrm{v} / \mathrm{v})$ hydrogen peroxide (Merck) in water to quench endogenous peroxidase activity, washed with PBS (5 min), incubated with blocking serum (UniTect Immunohistochemistry detection system; Oncogene Research Products) $(20 \mathrm{~min})$, washed again with PBS and then incubated overnight at $4^{\circ} \mathrm{C}$ with the primary antibody. Sections were rinsed three times in PBS ( 5 min each) before the addition of biotinylated horse anti-rabbit IgG secondary antibody (UniTect) diluted according to the manufacturer's instructions, for $30 \mathrm{~min}$, and then washed three times in PBS followed by application of peroxidase-conjugated avidinbiotin complex (Unitect) for $30 \mathrm{~min}$. Sections were washed in five changes of PBS, rinsed in 1\% ( $/ / \mathrm{v})$ Triton-X100-PBS (Sigma) (30 s) and visualized with 3, 3'-diaminobenzidine tetrahydrochloride (DAB; Dako Corporation, Carpentiria) (30-90 s) and with Harris' haematoxylin (BDH) as a counterstain. Sections were dehydrated through a $70 \%$, $90 \%$ and $100 \%$ ethanol series as described previously and mounted in DPX (BDH). The specificity of BAX and BCL-2 labelling was checked by: (i) parallel staining for antibodies 
Table 1. Oligonucleotide nested primer pairs for PCR of apoptotic genes and $\beta$-actin

\begin{tabular}{|c|c|c|c|c|c|c|c|}
\hline mRNA & $\begin{array}{l}\text { Type of } \\
\text { primer }\end{array}$ & $\begin{array}{l}\text { Sequence of forward } \\
\text { primer }\left(5^{\prime}-3^{\prime}\right)\end{array}$ & $\begin{array}{l}\text { Sequence of reverse } \\
\text { primer }\left(5^{\prime}-3^{\prime}\right)\end{array}$ & $\begin{array}{l}\text { Annealing } \\
\text { emperature } \\
\left({ }^{\circ} \mathrm{C}\right)\end{array}$ & $\begin{array}{l}\text { Product } \\
\text { size }(b p)\end{array}$ & $\begin{array}{l}\text { Digest } \\
\text { products } \\
\text { (bp) }\end{array}$ & $\begin{array}{c}\text { GenBank } \\
\text { accession } \\
\text { number }\end{array}$ \\
\hline \multirow[t]{2}{*}{ BCL-2 } & Outer & GGGTACGATAACCGGGAGAT & АСTTCACTTGTGGCСCAGAT & 52 & 702 & & \multirow[t]{2}{*}{ NM000633 } \\
\hline & Inner & GGATTGTGGССТTCTTTGAG & CAGCCAGGAGAAATCAAACAG & G 52 & 209 E & BamH I $(130,80)$ & \\
\hline \multirow[t]{2}{*}{$\mathrm{BAX}$} & Outer & GGGTACGATAACCGGGAGAT & CAGCCСАTСTTCTTCCAGAT & 52 & 507 & & \multirow[t]{2}{*}{ NM004324 } \\
\hline & Inner & CCAAGAAGCTGAGCGAGTGT & CAGCCCATGATGGTTCTGAT & 54 & $250 \mathrm{P}$ & Pst I $(60,190)$ & \\
\hline \multirow[t]{2}{*}{ BAD } & Outer & CCAGATCCCAGAGTTTGAGC & CCACCAGGACTGGAAGACTC & 55 & 460 & & \multirow[t]{2}{*}{ AF031523 } \\
\hline & Inner & CGAGTGAGCAGGAAGACTCC & CTGTGCTGCCCAGAGGTT & 54 & 299 & & \\
\hline \multirow[t]{3}{*}{$\beta$-actin } & Outer & ATCTGGCACCACACСTTCTAC & CGTCATACTCCTGCTTGCTGA & & & & \multirow{3}{*}{ NM001101 } \\
\hline & & AATGAGCTGCG & TCСАСАТСТGC & 65 & 838 & & \\
\hline & Inner & CGGGACCTGACTGACTACC & TGAAGGTAGTTTCGTGGATGC & 53 & 292 & & \\
\hline
\end{tabular}

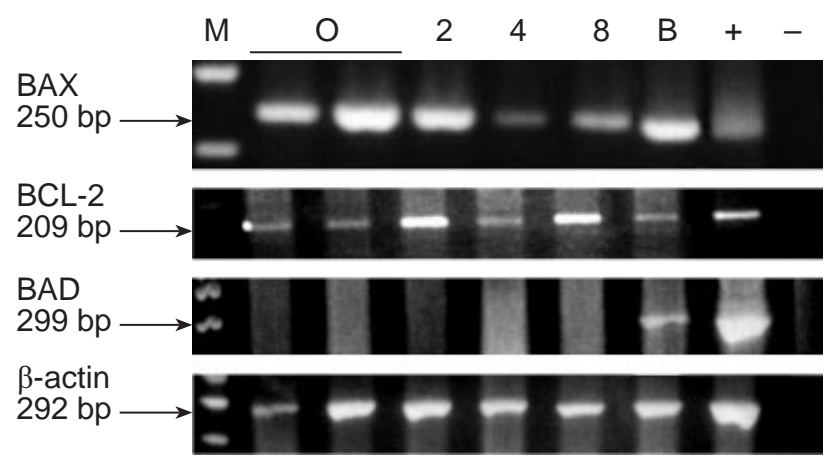

Fig. 1. Expression of $m R N A$ for $B A X, B C L-2, B A D$ and $\beta$-actin in individual human oocytes and embryos at all preimplantation stages of development. Lanes: M: 1 kb DNA ladder; O: oocyte; 2: two-cell embryo; 4: four-cell embryo; 8: eight-cell embryo; B: blastocyst; +: PCR positive control (fetal tissue cDNA); -: RT negative control.

in mouse gut sections (positive controls); (ii) omitting the primary antibody (negative control); and (iii) peptide competition experiments using peptide concentrations of 10 , 100, 200, 500 and $1000 \mu \mathrm{g} \mathrm{ml}^{-1}$. A 1:200 dilution of BAX peptide markedly reduced immunohistochemical labelling of BAX and dilutions of 1:20 and 1:2 completely obliterated any labelling. BCL-2 labelling was reduced at 1:20 dilution and completely prevented at a 1:2 dilution of BCL-2 peptide.

Sections were examined using an Eclipse TE300 inverted light microscope (Nikon UK, Kingston-upon-Thames). Images were captured at the same light intensity using a DXM1200 digital camera (Nikon UK) and LuciaTM digital image analysis software (Nikon UK). The intensity of staining was graded from - (no staining; equivalent to control sections) to + (pale staining), ++ (moderate staining) and +++ (darkest staining intensity).

\section{Caspase activity labelling}

CaspaTag ${ }^{\mathrm{TM}}$ fluorescein caspase activity kit (Intergen, Oxford Science Park, Oxford) was used to detect active caspases in failed-fertilized aged oocytes (days 3-6) and fresh or frozen-thawed embryos. The kit uses a carboxyfluorescein (FAM)-labelled broad-spectrum caspase inhibitor FAM-VAD-FMK, which is a potent inhibitor of caspase-3 and caspase-3-like caspases. It enters the cell and irreversibly binds to activated caspase-3, -8, -7, -10 and -6 in the order of decreasing activity, labelling them and allowing them to be visualized and localized.

After culture, embryos or oocytes were transferred to a 96-well, U-bottomed tissue culture plate (Falcon, BectonDickinson) and washed twice in approximately $100 \mu \mathrm{l}$ PBS-PVP. The zona pellucida was removed with a brief incubation in acid Tyrode's solution at room temperature and embryos were washed once more in PBS-PVP. Zona pellucida-free embryos and oocytes were incubated for $1 \mathrm{~h}$ at $37^{\circ} \mathrm{C}$ under $5 \% \mathrm{CO}_{2}$ in $10 \mu \mathrm{l}$ labelled caspase inhibitor (Caspatag; Intergen) and reconstituted in EBSS (according to manufacturer's instructions). Specimens were then fixed using 4\% (w/v) paraformaldehyde (Sigma) for $1 \mathrm{~h}$. Positive controls were incubated in $1 \mu \mathrm{mol}$ staurosporine $\mathrm{I}^{-1}$ (Sigma) overnight at $37^{\circ} \mathrm{C}$ and washed in PBS-PVP before labelling for caspase activity. After labelling, embryos were washed twice in PBS-PVP, mounted in Vectashield with 4,6diamidino-2-phenylindole (DAPI) $\left(1.5 \mu \mathrm{g} \mathrm{ml}^{-1}\right) \quad$ (Vector Laboratories, Peterborough) and stored in the dark at $4^{\circ} \mathrm{C}$ before two channel laser scanning confocal microscopy using a Leica TCS NT-SP-UV laser scanning confocal microscope (Leica, Milton Keynes).

\section{Results}

\section{Detection of $B A X, B C L-2$ and $B A D$ mRNA}

Expression of BAX, BAD and BCL-2 mRNA was studied in 78 failed-fertilized oocytes and preimplantation embryos at the two- to eight-cell, morula and blastocyst stages (Fig. 1, Table 2). Beta actin expression was detected in unfertilized oocytes and at all stages of preimplantation development. The embryos had two pronuclei on day 1, were not arrested and were developmentally on schedule. The expected $250 \mathrm{bp}$ and $209 \mathrm{bp}$ fragments encoding BAX and $\mathrm{BCL}-2 \mathrm{cDNA}$, respectively, were detected at the single oocyte and embryo level during all stages of preimplantation 
Table 2. Timing of expression of BAX, BCL-2 and BAD mRNA transcripts during human preimplantation development

\begin{tabular}{|c|c|c|c|c|c|c|c|}
\hline & \multicolumn{5}{|c|}{ Stage of embryo development } & \multicolumn{2}{|c|}{ Controls } \\
\hline & Oocyte & Two- to four-cell & 8-16-cell & Morula & Blastocyst & Granulosa & Placenta \\
\hline$\beta$-actin & $\begin{array}{c}+ \\
(19 / 19)\end{array}$ & $\begin{array}{c}+ \\
(22 / 22)\end{array}$ & $\begin{array}{c}+ \\
(21 / 21)\end{array}$ & $\begin{array}{c}+ \\
(7 / 7)\end{array}$ & $\begin{array}{c}+ \\
(15 / 15)\end{array}$ & + & + \\
\hline BAX & $\begin{array}{c}+ \\
(11 / 11)\end{array}$ & $\begin{array}{c}+ \\
(14 / 14)\end{array}$ & $\begin{array}{c}+ \\
(4 / 4)\end{array}$ & $\begin{array}{c}+ \\
(1 / 1)\end{array}$ & $\begin{array}{c}+ \\
(8 / 8)\end{array}$ & + & + \\
\hline BCL-2 & $\begin{array}{c}+ \\
(5 / 5)\end{array}$ & $\begin{array}{c}+ \\
(5 / 5)\end{array}$ & $\begin{array}{c}+ \\
(8 / 8)\end{array}$ & na & $\begin{array}{c}+ \\
(3 / 3)\end{array}$ & + & + \\
\hline BAD & $\begin{array}{c}- \\
(1 / 7)\end{array}$ & $\begin{array}{c}+/- \\
(2 / 9)\end{array}$ & $\begin{array}{c}- \\
(0 / 9)\end{array}$ & $\begin{array}{c}+ \\
(4 / 6)\end{array}$ & $\begin{array}{c}+ \\
(6 / 7)\end{array}$ & + & + \\
\hline
\end{tabular}

Numbers in parentheses represent the number of embryos expressing mRNA for gene of interest/number of embryos examined.

Some embryos were analysed for more than one mRNA.

na: not analysed.

development (Fig. 1, Table 2). However, transcripts encoding BAD were detected mainly after compaction (Fig. 1), although there was occasional amplification in early embryos (Table 2). The identity of the PCR products was confirmed by sequence and restriction digest analysis.

\section{Detection of $B A X$ and $B C L-2$ protein}

Twenty-two arrested and developing embryos (which had showed two pronuclei on day 1 ) were analysed for BAX and BCL-2 protein expression using immunohistochemistry. In the absence of primary antibody, no labelling was detected (Fig. 2). Control sections of mouse intestine showed intense labelling for BAX and BCL-2 (data not shown). Both $\mathrm{BAX}$ and $\mathrm{BCL}-2$ proteins were expressed in human embryos at the two- to eight-cell, morula and blastocyst stages (Fig. 2, Table 3). Generally, embryos of poor morphology had higher expression of both BAX and BCL-2 (Table 3). Within each embryo, staining for BAX and BCL-2 was heterogeneous (Fig. 2), demonstrating that each protein is differentially expressed in different cells.

\section{Caspase activity in human embryos}

Ten unfertilized oocytes, 22 arrested and 36 developing embryos were examined for the presence of active caspases (Table 4). In embryos that were developing on schedule, caspase activity was not evident before compaction and morula formation, with the exception of the polar bodies, which were intensely stained (Fig. 3, Table 4). Labelling of active caspases was absent in both fresh and frozen-thawed embryos before compaction. After compaction, $>50 \%$ of morulae had one or more caspase-positive cells, and most (> 90\%) of the blastocysts had cells with caspase activity. There was no qualitative difference in the amount of caspase labelling between morulae and blastocysts grown from fresh or cryopreserved embryos (Table 4). Anucleate cytoplasmic fragments were often labelled. In many cases the caspase labelling was associated with fragmented nuclei.

A small proportion of the arrested embryos examined had cells with active caspase labelling at the two- to fourcell stage (approximately 10\%) and five- to eight-cell stage (approximately 20\%) (Table 4). Two of these embryos (both fresh), one two- and one four-cell stage, were labelled on day 5 and had been arrested for $>3$ days.

\section{Discussion}

The present study has demonstrated, in human embryos, the expression of three major regulatory genes involved in apoptosis. BAX and BCL-2 mRNA and protein are expressed in unfertilized oocytes and throughout preimplantation development, whereas BAD mRNA is expressed mainly after compaction. Generally, amounts of BAX and BCL-2 protein are higher in embryos of poor morphology, with intense BAX staining in some fragments. Active caspases, the executors of cell death, are present after compaction in some morulae and most blastocysts, and are frequently associated with apoptotic nuclei.

Before compaction, BAD was undetectable in most embryos using the techniques described. However, transcripts were detected in most morulae and all blastocysts. This finding indicates that the embryo starts to express embryonic BAD after activation of the embryonic genome. This expression coincides with the appearance of DNA and nuclear fragmentation (characteristic of apoptosis) following compaction (Hardy et al., 2001), indicating that $B A D$ is a key regulatory protein in preimplantation apoptosis. BAD is central in the anti-apoptotic action of growth factors, such as IGF-I, which acts via the phosphatidylinositide 3'-OH kinase pathway (Datta et al., 1999). In other types of cell it has been shown that growth factor stimulation maintains BAD in a phosphorylated inactive state sequestered in the cytosol. Growth factor deprivation results in decreased PI-3 kinase pathway activity and BAD becomes dephosphorylated, allowing it to enter mitochondria, promoting apoptosis. In human embryos, IGF-I has been shown to reduce apoptosis and increase blastocyst formation (Spanos et al., 2000).

These findings confirm observations in mouse 
(a)
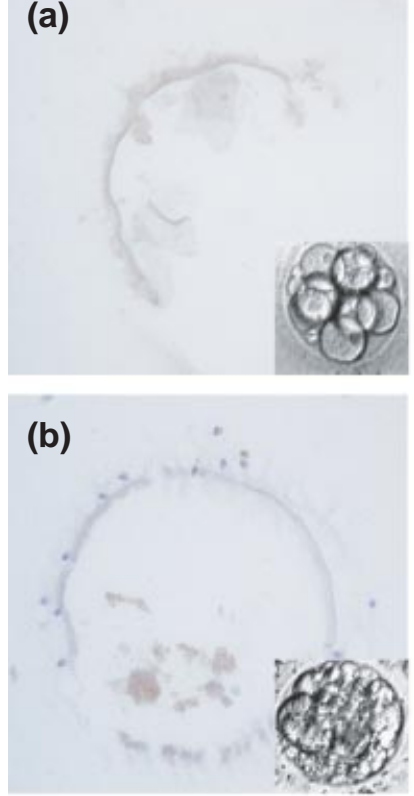

(c)
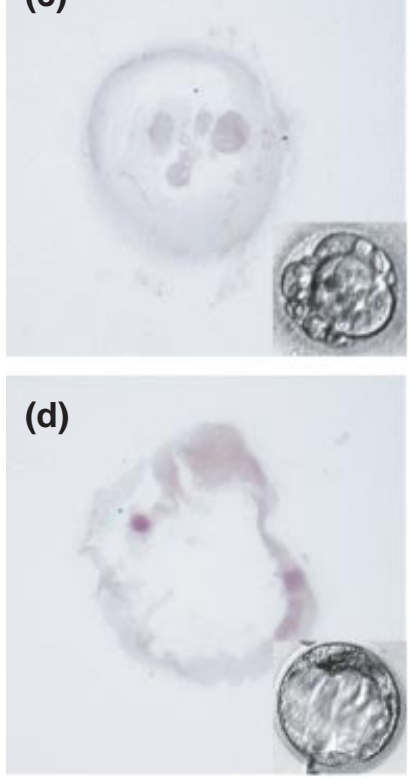

(e)

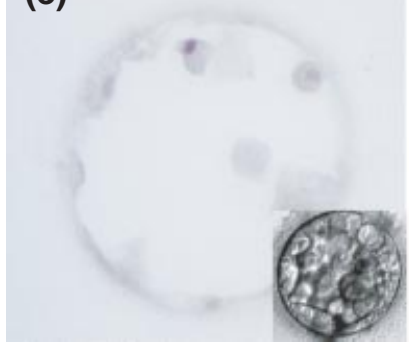

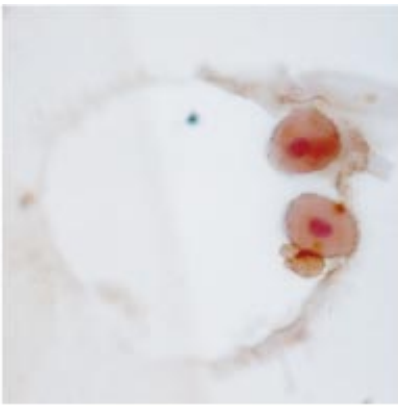
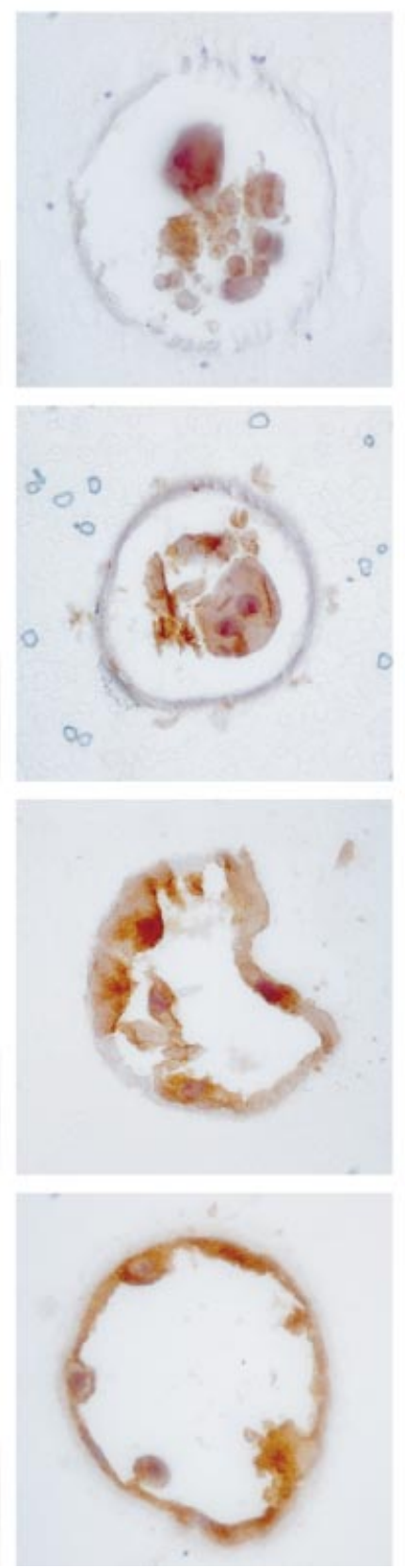
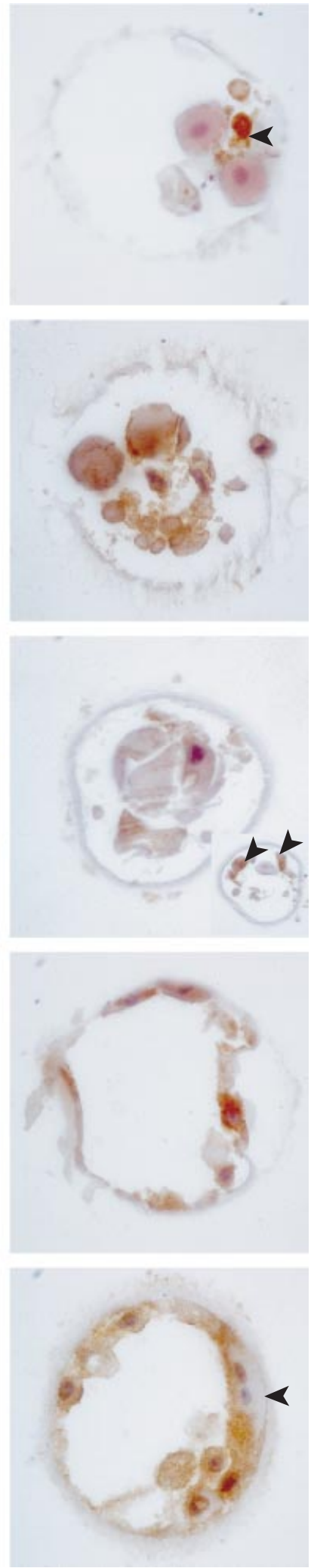

Fig. 2. Immunohistochemical localization of $B C L-2$ and $B A X$ in two pronucleate human preimplantation embryos. Each row consists of sections from the same embryo. Left hand column: control; middle column: BCL-2; right hand column: BAX. Insets in control sections are light micrographs of embryos before fixation. (a) Day 4 eight-cell embryo of good morphology. Note 
Table 3. Summary of immunohistochemical staining of BCL-2 and $B A X$ in preimplantation human embryos

\begin{tabular}{lccccc}
\hline Embryo stage & Day & $n$ & Morphology & Bcl-2 & Bax \\
\hline Two- to eight-cell & $3-4$ & 3 & Good & ++ & + \\
& $3-4$ & 3 & Poor & +++ & +++ \\
Arrested one- to eight-cell & 5 & 4 & Mixed & ++ & ++ \\
Morula & $4-5$ & 5 & Poor & ++ & ++ \\
Blastocyst & $4-6$ & 3 & Good & ++ & + \\
& $5-6$ & 4 & Poor & +++ & ++ \\
\hline
\end{tabular}

All embryos had two pronuclei on day 1 .

$n=$ number of embryos examined.

aay $0=$ day of insemination.

Table 4. Active caspase labelling in fresh and frozen-thawed human preimplantation embryos (two pronucleate on day 1)

\begin{tabular}{|c|c|c|c|c|c|c|}
\hline Stage & Daya & $n$ & $\begin{array}{l}\text { Fresh/frozen } \\
\text {-thawed }\end{array}$ & $\begin{array}{l}\text { Average number } \\
\text { of nucleib }\end{array}$ & $\begin{array}{l}\text { Number of embryos } \\
\text { with labelled cells }\end{array}$ & $\begin{array}{c}\text { Description of caspase } \\
\text { activity }\end{array}$ \\
\hline Fertilized one-cell & 2 & 1 & Thawed & 1 & 0 & No labelling \\
\hline \multirow[t]{2}{*}{$\begin{array}{l}\text { Unfertilized arrested } \\
\text { one-cell }\end{array}$} & $3-6$ & 6 & Fresh & 1 & 2 & $\begin{array}{l}\text { Labelled oocytes day } 4 \\
\text { and day } 5\end{array}$ \\
\hline & $2-3$ & 4 & Thawed & 1 & 1 & Labelled oocyte day 3 \\
\hline \multirow[t]{2}{*}{ Two- to eight-cell } & $2-3$ & 6 & Fresh & $\begin{array}{l}7.3 \pm 0.7 \\
\quad(n=6)\end{array}$ & 0 & $\begin{array}{l}\text { Only polar bodies } \\
\text { labelled }\end{array}$ \\
\hline & $2-4$ & 10 & Thawed & $\begin{array}{l}5.1 \pm 0.8 \\
(n=9)\end{array}$ & 0 & $\begin{array}{l}\text { Only polar bodies } \\
\text { labelled }\end{array}$ \\
\hline $\begin{array}{l}\text { Arrested two- to } \\
\text { eight-cell }\end{array}$ & $3-5$ & 21 & Fresh & $\begin{array}{c}3.5 \pm 0.5 \\
(n=19)\end{array}$ & 3 & $\begin{array}{l}\text { Labelled embryos day } 4 \\
\text { and } 5 . \text { Three embryos } \\
\text { had labelled fragments }\end{array}$ \\
\hline \multirow[t]{2}{*}{ Morula } & $3-4$ & 5 & Fresh & $\begin{array}{c}10.0 \pm 1.4 \\
(n=5)\end{array}$ & 1 & $\begin{array}{l}\text { Two embryos with } \\
\text { labelled anucleate } \\
\text { fragments }\end{array}$ \\
\hline & $4-5$ & 3 & Thawed & $\begin{array}{c}11.0 \pm 3.6 \\
(n=3)\end{array}$ & 3 & $\begin{array}{l}\text { One cell positive in } \\
\text { each embryo }\end{array}$ \\
\hline \multirow[t]{2}{*}{ Blastocyst } & $5-6$ & 5 & Fresh & $\begin{array}{l}43.8 \pm 9.9 \\
\quad(n=4)\end{array}$ & 4 & $\begin{array}{l}\text { One or more positive } \\
\text { cells }\end{array}$ \\
\hline & 5 & 7 & Thawed & $\begin{array}{l}30.4 \pm 5.9 \\
\quad(n=7)\end{array}$ & 7 & $\begin{array}{l}\text { One or more positive } \\
\text { cells }\end{array}$ \\
\hline
\end{tabular}

aDay 0 = day of insemination.

${ }^{b}$ Values are mean $\pm \operatorname{SEM}$ ( $n=$ number of embryos for which it was possible to accurately determine number of cells).

$n=$ number of embryos examined.

preimplantation embryos. Bcl-2 and Bax transcripts were detected at all stages examined from the zygote to the blastocyst (Jurisicova et al., 1998; Warner et al., 1998b; Exley et al., 1999). Exley et al. (1999) were unable to detect
Bad mRNA in mouse embryos, but small amounts were occasionally detected in oocytes. Jurisicova et al. (1998) detected small amounts during cleavage, and there was an increase in expression at the blastocyst stage. This finding is

fragment with intense BAX labelling (arrowhead). (b) Day 4 cleavage stage embryo of poor morphology with extensive fragmentation. (c) Day 4 morula with excluded cells. Note pale BAX staining except for fragments (arrows, inset). (d) Day 4 blastocyst of good morphology. Note paler BAX labelling compared with (e). (e) Day 5 blastocyst of poor morphology. Note heterogeneous expression of BAX labelling (arrowhead). 

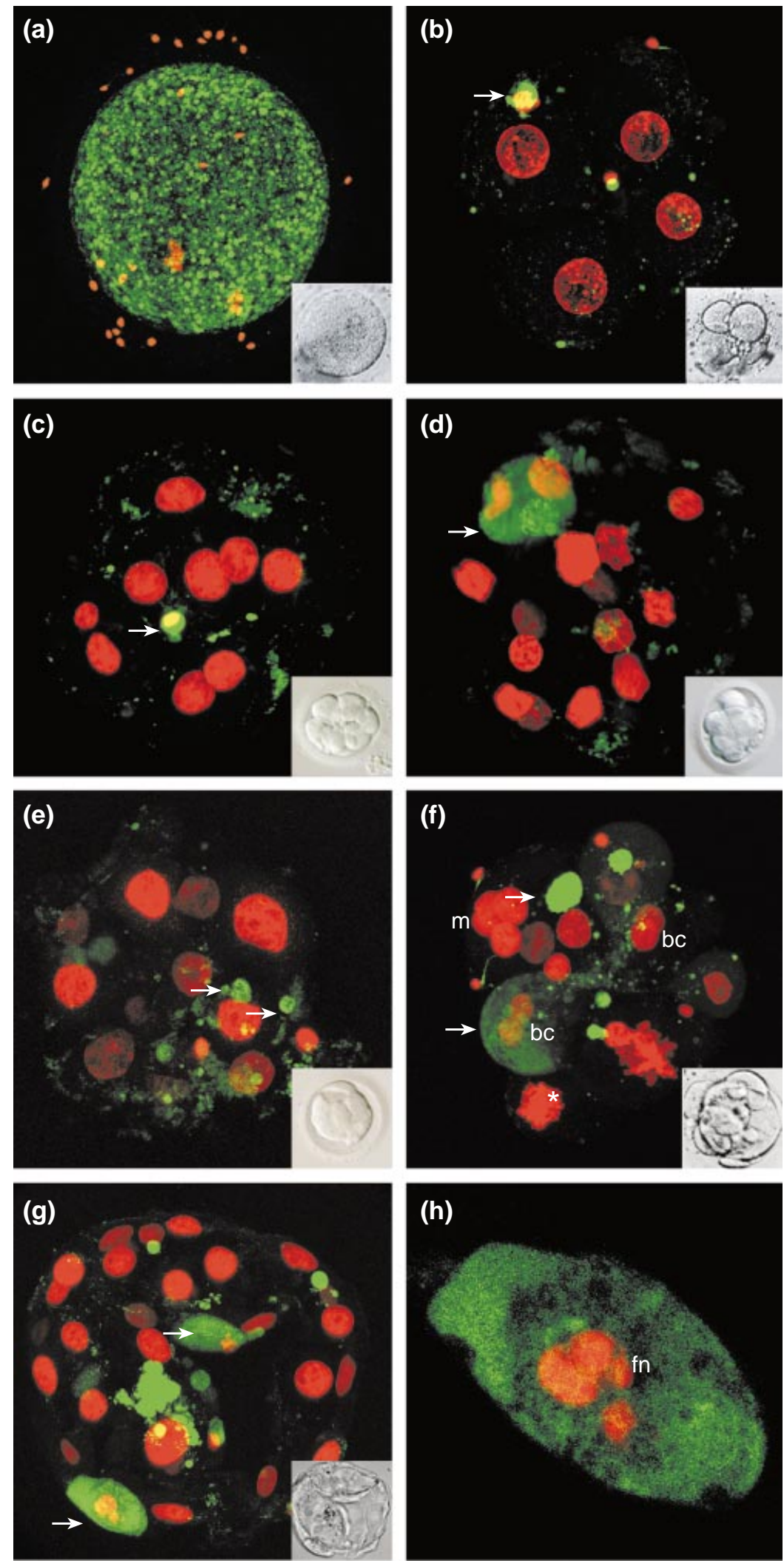

Fig. 3. Confocal projections showing fluorescent labelling of active caspases in human preimplantation embryos. Nuclei, labelled with 4,6-diamino-2-phenyline (DAPI), are artificially coloured in red for clarity; cells and fragments labelled for 
similar to the observations in the present study of occasional expression ( $12 \%$ of embryos) before compaction, and more consistent expression in morulae and blastocysts. In addition, mouse embryos have been shown to express a range of caspase-related genes (Exley et al., 1999). Collectively, this evidence supports the theory of a 'universal' mechanism of apoptosis that occurs during early embryogenesis as well as in many other types of cell.

Caspase activity appears only after compaction in both fresh and frozen-thawed embryos. Generally, activecaspase-positive cells are correlated with nuclear fragmentation. The present study has shown that the timing of expression of active caspases coincided with the onset of $\mathrm{BAD}$ expression and also with the onset of apoptosis reported by Hardy et al. (2001). Weil et al. (1996) reported that early embryos were more resistant to induced apoptosis than were cells in the blastocyst and hypothesized that a functional apoptotic pathway may be suppressed during early development (Weil et al., 1996). The expression of apoptosis genes throughout mouse and human preimplantation development (this study and Exley et al., 1999), coupled with the late onset of morphological signs of apoptosis after compaction or even blastocyst formation in a variety of species (Brison and Schultz, 1997; Long et al., 1998; Byrne et al., 1999; Hardy et al., 2001), certainly supports the hypothesis that although the apoptotic machinery is present throughout development, apoptosis is inhibited during early cleavage stages. Possible candidates for suppressing apoptosis during early cleavage include inhibitors of apoptosis (IAPs), which directly inhibit active caspases (Goyal, 2001).

The general absence of morphological signs of apoptosis before compaction or blastocyst formation in mammalian embryos is intriguing. It is possible that, in contrast to cells in the blastocyst, in which phagocytosis has been observed (Hardy et al., 1996), cleavage stage blastomeres do not have the ability to phagocytose dying cells. The final 'clearing away' of cell debris by phagocytosis is a crucial step in the apoptotic pathway and if it does not occur the apoptotic cells could lyse, and their caspase-packed cytoplasm could damage adjacent healthy cells (Henson et al., 2001). It is possible that in the absence of an efficient waste disposal system, it is too dangerous to the health of the embryo as a whole to risk release of lytic cell contents from dying cells within the close confines of the zona pellucida. Large, arrested cells can persist in the blastocoel or between the trophectoderm and the zona pellucida (Hardy, 1999), providing evidence that cleavage stage blastomeres are incapable of phagocytosis and removal of these cells.

There are a number of other possible reasons why apoptosis does not start until after compaction. The morula stage is a critical developmental stage which follows activation of the embryonic genome and immediately precedes blastocyst formation with the formation of the first differentiated types of cell. Gap junctions and other junctions only start to be extensively expressed at compaction (Fleming et al., 1992; Hardy et al., 1996). Recently, gap junctions were shown to propagate apoptotic signals between cells (Lin et al., 1998), and a specific gap junction protein (connexin 31.1) was shown to be uniquely expressed in atretic follicles in the mouse ovary (Wright et al., 2001). These observations indicate that the establishment of cell-cell communication may be important in the onset of apoptosis.

Finally, it is becoming clear that cell cycle progression and apoptosis are closely linked, and that apoptosis is induced when cell division and cell cycle progression have 'gone astray' (Los et al., 2001). Binucleate cells, probably produced by a failure of cytokinesis (Hardy et al., 1993), and chromosomally abnormal cells, resulting from post-zygotic mitotic non-disjunction (Handyside and Delhanty, 1997), are common throughout preimplantation development. It is unclear whether these cell cycle anomalies are genetic in origin or result from a suboptimal environment. Thus, cell cycle defects are common during preimplantation development and may be linked to increasing amounts of apoptosis, particularly after compaction.

The link between apoptosis and embryo quality is complex. Cytoplasmic fragments are common in human embryos (Alikani et al., 1999) and it has been proposed that they are equivalent to apoptotic bodies as they can contain fragmented DNA (Jurisicova et al., 1996) and express active caspases (Exley et al., 1999; Xu et al., 2001). However, failure to (i) consistently observe apoptotic markers in cytoplasmic fragments (Antczak and Van Blerkom, 1999), (ii) reduce fragmentation with caspase inhibitors ( $\mathrm{Xu}$ et al., 2001) and (iii) observe active caspases in all fragments (this study) all support the contention that apoptosis and cytoplasmic fragmentation are not always related. Fragments that have persisted for some time may undergo secondary necrosis, with membrane and DNA changes indistinguishable from those seen during apoptosis. The occurrence of apoptotic cells in vivo (Handyside and Hunter, 1986) indicates that apoptosis plays a role in normal development,

caspase activity are shown in green. Light micrographs of embryos before labelling are shown in insets. (a) Day 5 arrested germinal vesicle (GV) stage oocyte with entire ooplasm stained positive for caspase activity. Note punctate staining. (b) Day 2 four-cell embryo with labelled polar bodies (arrow). (c) Day 3 eight-cell embryo of excellent morphology with nine nuclei and only the polar bodies labelled for caspase activity (arrow). (d) Day 3 compacting embryo with 15 nuclei showing one caspase-labelled cell (arrow). (e) Early blastocyst with 11 nuclei. Although none of the cells are positive, anucleate fragments (arrows) are stained positively for caspase activity. (f) Day 6 blastocyst of poor morphology with approximately 12 nuclei. Note multinucleate blastomere (m), binucleate cells (bc) (one of which is positively labelled for active caspases), mitotic cell $\left(^{*}\right)$ and caspase labelled cells and blebs (arrows). (g) Day 6 expanded blastocyst with 31 nuclei with cells labelled positive for caspase activity (arrows). (h) Enlarged confocal projection of a caspase-labelled cell with fragmented nucleus (fn) from day 6 expanded blastocyst (g). 
although amounts can be increased under suboptimal culture conditions (Brison and Schultz, 1997; Devreker and Hardy, 1997; Pampfer et al., 1997; Moley et al., 1998; Spanos et al., 2000). Thus, suboptimal culture conditions could increase rates of apoptosis to a level at which embryo development and pregnancy outcome is compromised.

The present study has demonstrated that common participants in the apoptotic cascade (BCL-2 and BAX) are present throughout human preimplantation development. In addition, the present study has shown that a proposed intermediate in the IGF-I survival pathway, BAD, is expressed mainly after compaction. Finally, the executors of cell death, active caspases, are present after compaction and are frequently associated with apoptotic nuclei. Together with our previous report that two morphological features of apoptosis, fragmenting nuclei and DNA, appear after compaction (Hardy et al., 2001), observations from the present study indicate that apoptosis is inhibited during early cleavage. However, the reasons for particular cells within the morula and blastocyst undergoing apoptosis are still unclear and the early signalling events that trigger an embryo cell to die are unknown.

The authors would like to thank the Wolfson IVF Unit. The authors are grateful for the confocal microscopy assistance of D. Ciantar.

\section{References}

Adams JM and Cory S (2001) Life-or-death decisions by the Bcl-2 protein family Trends in Biochemical Sciences 26 61-66

Alikani M, Cohen J, Tomkin G, Garrisi GJ, Mack C and Scott RT (1999) Human embryo fragmentation in vitro and its implications for pregnancy and implantation Fertility and Sterility 71 836-842

Antczak M and Van Blerkom J (1999) Temporal and spatial aspects of fragmentation in early human embryos: possible effects on developmental competence and association with the differential elimination of regulatory proteins from polarized domains Human Reproduction 14 429-447

Aravind L, Dixit VM and Koonin EV (1999) The domains of death: evolution of the apoptosis machinery Trends in Biochemical Sciences 24 47-53

Bernardi P, Petronilli V, Di Lisa F and Forte M (2001) A mitochondrial perspective on cell death Trends in Biochemical Sciences 26 112-117

Betts DH and King WA (2001) Genetic regulation of embryo death and senescence Theriogenology 55 171-191

Brison DR and Schultz RM (1997) Apoptosis during mouse blastocyst formation: evidence for a role for survival factors including transforming growth factor alpha Biology of Reproduction 56 1088-1096

Byrne AT, Southgate J, Brison DR and Leese HJ (1999) Analysis of apoptosis in the preimplantation bovine embryo using TUNEL Journal of Reproduction and Fertility 117 97-105

Datta SR, Brunet A and Greenberg ME (1999) Cellular survival: a play in three Akts Genes and Development 13 2905-2927

Dawson KJ, Conaghan J, Ostera GR, Winston RM and Hardy K (1995) Delaying transfer to the third day post-insemination, to select nonarrested embryos, increases development to the fetal heart stage Human Reproduction 10 177-182

Devreker F and Hardy K (1997) Effects of glutamine and taurine on preimplantation development and cleavage of mouse embryos in vitro. Biology of Reproduction 57 921-928

Devreker F, Winston RM and Hardy K (1998) Glutamine improves human preimplantation development in vitro. Fertility and Sterility $69293-299$

Earnshaw WC, Martins LM and Kaufmann SH (1999) Mammalian caspases: structure, activation, substrates and functions during apoptosis Annual Reviews of Biochemistry $\mathbf{6 8} 383-424$
Exley GE, Tang C, McElhinny AS and Warner CM (1999) Expression of caspase and BCL-2 apoptotic family members in mouse preimplantation embryos Biology of Reproduction 61 231-239

Fleming TP, Javed Q and Hay M (1992) Epithelial differentiation and intercellular junction formation in the mouse early embryo Development Supplement 105-112

Gilliland G, Perrin S and Bun HF (1990) PCR Protocols: A Guide to Methods and Applications Academic Press, New York

Goyal L (2001) Cell death inhibition: keeping caspases in check Cell $\mathbf{1 0 4}$ 805-808

Handyside A and Delhanty J (1997) Preimplantation genetic diagnosis: strategies and surprises Trends in Genetics 13 270-275

Handyside AH and Hunter S (1986) Cell division and death in the mouse blastocyst before implantation Roux's Archives of Developmental Biology 195 519-526

Hardy K (1997) Cell death in the mammalian blastocyst Molecular Human Reproduction 3 919-925

Hardy K (1999) Apoptosis in the human embryo Reviews of Reproduction 4 $125-134$

Hardy K, Winston RM and Handyside AH (1993) Binucleate blastomeres in preimplantation human embryos in vitro: failure of cytokinesis during early cleavage Journal of Reproduction and Fertility 98 549-558

Hardy K, Warner A, Winston RM and Becker DL (1996) Expression of intercellular junctions during preimplantation development of the human embryo Molecular Human Reproduction 2 621-632

Hardy K, Spanos S, Becker D, lannelli P, Winston RM and Stark J (2001) From cell death to embryo arrest: mathematical models of human preimplantation embryo development Proceedings National Academy of Sciences USA 98 1655-1660

Henson PM, Bratton DL and Fadok VA (2001) The phosphatidylserine receptor: a crucial molecular switch? Nature Reviews Molecular Cell Biology 2 627-633

Hsu YT, Wolter KG and Youle RJ (1997) Cytosol-to-membrane redistribution of $\mathrm{Bax}$ and $\mathrm{BCl}-\mathrm{X}(\mathrm{L})$ during apoptosis Proceedings National Academy of Sciences USA 94 3668-3672

Jurisicova A, Varmuza S and Casper RF (1996) Programmed cell death and human embryo fragmentation Molecular Human Reproduction 2 93-98

Jurisicova A, Latham KE, Casper RF and Varmuza SL (1998) Expression and regulation of genes associated with cell death during murine preimplantation embryo development Molecular Reproduction and Development $51243-253$

Lin JH-C, Weigel H, Cotrina M, Liu S, Bueno E, Hansen A, Hansen T, Goldman S and Nedergaard M (1998) Gap-junction-mediated propagation and amplification of cell injury Nature Neuroscience 1 494-500

Liu HC, He ZY, Mele CA, Veeck LL, Davis O and Rosenwaks Z (2000) Expression of apoptosis-related genes in human oocytes and embryos Journal of Assisted Reproduction and Genetics 17 521-533

Long CR, Dobrinsky JR, Garrett WM and Johnson LA (1998) Dual labeling of the cytoskeleton and DNA strand breaks in porcine embryos produced in vivo and in vitro. Molecular Reproduction and Development $\mathbf{5 1} 59-65$

Los M, Stroh C, Janicke RU, Engels IH and Schulze-Osthoff K (2001) Caspases: more than just killers? Trends in Immunology 22 31-34

Matwee C, Betts DH and King WA (2000) Apoptosis in the early bovine embryo Zygote 8 57-68

Moley KH, Chi MM, Knudson CM, Korsmeyer SJ and Mueckler MM (1998) Hyperglycemia induces apoptosis in pre-implantation embryos through cell death effector pathways Nature Medicine 4 1421-1424

Nagata S (2000) Apoptotic DNA fragmentation Experimental Cell Research $25612-18$

Oltvai ZN, Milliman CL and Korsmeyer SJ (1993) BCl-2 heterodimerizes in vivo with a conserved homolog, Bax, that accelerates programmed cell death Cell 74 609-619

Pampfer S, Vanderheyden I, McCracken JE, Vesela J and De Hertogh R (1997) Increased cell death in rat blastocysts exposed to maternal diabetes in utero and to high glucose or tumor necrosis factor-alpha in vitro. Development 124 4827-4836

Pampfer S, Cordi S, Vanderheyden I, Van Der Smissen P, Courtoy PJ, Van Cauwenberge A, Alexandre H, Donnay I and De Hertogh R (2001) 
Expression and role of $\mathrm{Bcl}-2$ in rat blastocysts exposed to high D-glucose Diabetes 50 143-149

Ponte P, Ng SY, Engel J, Gunning P and Kedes L (1984) Evolutionary conservation in the untranslated regions of actin mRNAs: DNA sequence of a human beta-actin cDNA Nucleic Acids Research 12 1687-1696

Spanos S, Becker DL, Winston RM and Hardy K (2000) Anti-apoptotic action of insulin-like growth factor-I during human preimplantation embryo development Biology of Reproduction 63 1413-1420

Tsujimoto Y and Shimizu S (2000) Bcl-2 family: life-or-death switch FEBS Letters 466 6-10

Vieira HL and Kroemer G (1999) Pathophysiology of mitochondrial cell death control Cellular and Molecular Life Sciences 56 971-976

Wang HG and Reed JC (1998) Mechanisms of Bcl-2 protein function Histology and Histopathology 13 521-530

Warner CM, Cao W, Exley GE, McElhinny AS, Alikani M, Cohen J, Scott RT and Brenner CA (1998a) Genetic regulation of egg and embryo survival Human Reproduction 13 Supplement 3 178-196

Warner CM, Exley GE, McElhinny AS and Tang C (1998b) Genetic regulation of preimplantation mouse embryo survival Journal of Experimental Zoology 282 272-279
Weil M, Jacobson MD, Coles HS, Davies TJ, Gardner RL, Raff KD and Raff MC (1996) Constitutive expression of the machinery for programmed cell death Journal of Cell Biology 133 1053-1059

Wolter KG, Hsu YT, Smith CL, Nechushtan A, Xi XG and Youle RJ (1997) Movement of Bax from the cytosol to mitochondria during apoptosis Journal of Cell Biology 139 1281-1292

Wright CS, Becker DL, Lin JS, Warner AE and Hardy K (2001) Stage-specific and differential expression of gap junctions in the mouse ovary: connexin-specific roles in follicular regulation Reproduction 121 77-88

Wyllie AH (1995) The genetic regulation of apoptosis Current Opinion in Genetics and Development 5 97-104

Xu J, Cheung T, Chan ST, Ho P and Yeung WS (2001) The incidence of cytoplasmic fragmentation in mouse embryos in vitro is not affected by inhibition of caspase activity Fertility and Sterility 75 986-991

Received 20 March 2002.

First decision 16 May 2002.

Revised manuscript received 27 May 2002.

Accepted 27 May 2002. 
